\title{
Transformations of Byron in the Literature of British India Máire ní Fhlathúin
}

\author{
Lord help me! I am little of a sage \\ In turning rhymer at the present time, \\ When your Byronean stanzas are the rage \\ Among the monarchs of the realms of rhyme \\ (“Ins and Outs: A Satire of 1833," Oriental Observer 16 Feb 1833)
}

This essay examines the reception of Byron's work, and some responses to it, among the poets of the British community in India during the first half of the nineteenth century. The first section sketches some of the routes by which Byron's work and accounts of his life were circulated and read in India and demonstrates the impact of his work on the poets of British India. These poets co-opted Byronic texts into their own writings in the form of epigraphs and other citations and allusions, composed responses to Byron and his work, and imitated the tropes, formats and themes of Byron's poetry. The second section of the essay looks in more detail at selected examples of the many adaptations and imitations of Byron's work that proliferated during this period. In these poems, Byronic models are appropriated by writers whose chosen professions or relationships have the effect of aligning them with the colonial project of the East India Company. They re-imagined the encounter with the romanticized Orient that characterizes many of Byron's works in response to the specific political and cultural contexts of British India in the nineteenth century.

\section{Reading Byron in India}

The market for Anglophone poetry in colonial India included both British and Indian consumers, and Byron's readers were to be found in both communities, as were writers who adopted him as a model. Among works by Indian writers, a notable example is an early poem by H. L. V. Derozio: "Don Juanics” appeared in the India Gazette in 1825-26, its Juan a traveller to Calcutta who can self-referentially "quote / Lord Byron, Moore, and other bards of note" (Derozio 48). The English-language poetry of Kasiprasad Ghosh and Michael Madhusudan Dutt bears the imprint of the authors' reading of Byron, and his work was translated and otherwise appropriated by writers using several of the other languages of India. ${ }^{1}$ This essay is, however, mainly concerned with the British readership of Byron in India. 
The composition of Byron's reading constituency in British India mirrored that of the metropolitan readership of the same period. In Britain, Byron was high on the list of "canonical eight" writers identified by William St Clair. Childe Harold's Pilgrimage and the Eastern Tales (especially “The Corsair," "The Giaour," and "The Bride of Abydos”) and other works sold in large numbers, while Don Juan was "by far the biggest seller of any contemporary literary work during the romantic period" and continued to be read throughout the nineteenth century $(217,218,333)$. Some of these British readers also responded to Byron's work with literary activities of their own, engaging in appropriations of Byronic texts of varying levels of creativity, from including extracts in private miscellanies or commonplace books, to composing satires based on his work, especially Don Juan, or making the figure of Byron himself a subject for verse. ${ }^{2}$ This trend extended beyond Britain: Byron's work was widely read across Europe, and his major early poems, the Eastern Tales and Childe Harold's Pilgrimage, became what Diego Saglia has termed "determining influences" on European Romantic writings on the Orient (471-472).

Responses to Byron's work in India fall into a similar pattern, reflecting the ways in which the Anglophone literary marketplace in India depended on and mirrored its metropolitan counterpart. Both economic and cultural factors - the relatively small pool of writers and readers in British India, the cost-effectiveness of importing books versus printing them locally, as well as the gravitational pull of home productions for exile readers - underlie this dependence (ní Fhlathúin 1.xli-xlii). Books and periodicals published in London were widely available to readers in Bengal from the 1820s onward through lending libraries as well as booksellers. ${ }^{3}$ Byron's works are among those most often found in the possession of these readers, as Matthew Adams's study of book ownership in British India demonstrates. Further evidence for the availability of Byron's work and for the passionate interest with which many readers responded to it may be found in the columns of the periodicals of British India. The analysis below focuses first on an examination of one periodical, the Calcutta Journal (18181823). Under its radical, combative editor J.S. Buckingham, this paper was politically aligned with the revolutionary and romantic strain in Byron's writings and became an important conduit for his work in India during the relatively short period of its existence. ${ }^{4}$ Other periodicals and books, particularly the Oriental Observer (1827-1841), provide evidence for the enduring impact of Byron's work in the period following his death. ${ }^{5}$

The demand for reading material imported from Britain, and the difficulty experienced in obtaining it by readers in upcountry stations away from the major centers of population, provided the Calcutta Journal with a marketing opportunity. "Mazeppa" and 
various shorter pieces by Byron, and some reviews of his work, were reprinted in the paper during $1819 .{ }^{6}$ In the final days of that year, there also appeared an advertisement for the forthcoming publication of another Byron work: "The kindness of a Friend, who has supplied us with one of the few copies of Don Juan that have come out by the Rochester, will enable us to gratify our Readers at remote Stations, by an early republication of the whole of this celebrated Poem" ("Lord Byron's Don Juan” CJ 30 Dec 1819). The first two cantos take up the whole of the paper for two issues and part of a third, although some of the stanzas are omitted on the grounds of "profanity and obscenity"; the next day saw the publication of the paper's review of the whole (CJ 3, 4, 5, 6 Jan 1820). Further extracts from Don Juan appeared over the following years, as well as other works by Byron and articles of biography and criticism referring to him and his work, both original essays and those copied from metropolitan papers. ${ }^{7}$

Originating locally rather than reprinted from imported sources, some of these contributions suggest a high degree of engagement with the themes and forms of Byron's work on the part of their writers. Both Childe Harold's Pilgrimage and Don Juan form the topic of on-going critical debates, while another correspondence concerns Byron's having “copied, (while he has Byronized,) the language" of Harriet Lee's Kruitzer: The German's Tale in his poem Werner. ${ }^{8}$ Poetic responses to Byron and his work, both celebratory and condemnatory, appear alongside these critical essays. In the anonymous "Stanzas: Written after reading the Fourth Canto of Childe Harold," Byron is placed among the "intellectual masters of mankind" and his work credited with the power to restore a "declining Venice" to a stature "[a]bove the reach of envy or of time" (CJ 8 Dec 1819). Some of those who celebrated Byon and his work at this time would go on to become well-known in their own right in British India. The writer and editor D. L. Richardson, for instance, writes of Byron's "Minstrel's magic art / that calms the fever of the heart" in the poem "To Lord Byron" (CJ 20 May 1822); and Bernard Wycliffe (an alias for the poet and essayist Henry Meredith Parker) praises "mighty Byron's harp of fire" in "The Prayer" (CJ 14 Feb 1822). Taking a contrary view, other texts identify Byron as a diabolic figure, "[i]nspir'd by Satan," his "Demon's art" and "Seraph's tongue" models to be avoided by aspiring poets ("On Lord Byron" CJ $10 \mathrm{Sept}$ 1822). ${ }^{9}$ In these instances, the Calcutta Journal demonstrates not only the presence of Byron's work in British India, but also the degree to which it figured as a topic for discussion among its readers.

Following the demise of the Calcutta Journal, Byron's poetry continued to be reprinted and the details of his scandalous life discussed across a range of other publications, 
both in Calcutta and, as time went on, across British India. These publications included the Calcutta Magazine (which published several biographical reviews) and the Calcutta Literary Gazette. ${ }^{10}$ In the Oriental Observer, which took much of its material from British publications, Byron's own works appear alongside poems by others written to or about him: "The Bards" celebrates Byron together with Shakespeare and Milton (2 Aug 1829), and other such works include "Lines: Reading Moore's Life of Byron," by Catherine Head (15 Aug 1830); "Last Words of Lord Byron" (16 Sept 1832); and a "Monody on the Death of Lord Byron" (14 Aug 1831). ${ }^{11}$ Such poetic responses also occur outside of the columns of the periodical press, and outside of the Bengal presidency (from which most of the preceding examples are taken). Shrikant R. Tambe describes poems based on Byronic models, and discussions of his writings, in the Bombay papers of the 1840s (162). In Madras, a writer signing himself "Delta" devotes a passage of verse to the account of a visit to the castle of Chillon and takes issue with Byron's description of its "dark and dim" dungeon, remarking in a footnote that the room in question "was sufficiently light to enable me to read without difficulty the small print of a pocket edition of 'un guide en suisse,' which I had in my hand." 12 In the decade following Byron's death, he is remembered by readers such as James Hutchinson, whose "Lament for Lord Byron" runs to 50 lines (Sunyassee 189-92). Four decades later, the enduring nature of his memory is apparent when his work is satirized by others such as Aliph Cheem (Walter Yeldham), who contrasts the intellectual pleasures of poetry, embodied in "Lord Byron" who "of sweets most enchantingly sings," with the material joys of the bath: "nothing in Ind half so sweet as a plunge / In a jolly big tub, with a jolly big sponge!" (72). The bathos of the image is in keeping with the anti-intellectual nature of Yeldham's comic verse more generally, but it also suggests the extent to which Byron's status as celebrity poet has come to overshadow his work (the fact that his poetry is for the most part far removed from the "sweet" is not permitted to interfere with the appropriation of his image). When the editor of the Bombay Gazette reaches for a disparaging term to describe the unfortunate Indian writer Manuckjee Cursetjee, turned down for membership of the Literary Society of Bombay, he refers to him as "the discomfited Byron of the East" (Asiatic Journal Apr 1834 255). In such episodes, the name and persona of Byron are mapped directly on to the abstract notion and figure of the poet, indicating both the weight carried by his reputation in British India and the relationship of inequality and derivation implied between the literature of the colony and that of the imperial centre. 
The extent of Byron's influence on the writers of British India is further evidenced by their engagement with their Byronic models. In the first half of the nineteenth century, we can see an ongoing use of Byronic metre, concerns, and voice, sometimes in direct imitation or parody, but also in indirect and allusive appropriation. ${ }^{13}$ These texts highlight the specific concerns of British India and its literary community's status as peripheral to and dependant on the metropole, but they also highlight the ability of its writers to use Byronic models to delineate their own relationship to literary and political structures of power. The remainder of this essay examines a selection of these adaptations, looking at three areas in particular: epigraphs and quotations from Byron's work; satires based on his poetry, particularly Don Juan; and transformations of the Byronic hero in the colonial context.

\section{Epigraphs and Quotations from Byron's Work}

Given Byron's fame during this period, it is perhaps not surprising that epigraphs and quotations taken from his work often appear to function as borrowed light. These epigraphs and quotations illuminate the intertext in the manner indicated by Genette's suggestion that the epigraph may sometimes be important not for "what it says but who its author is" (Paratexts 159). There are many instances of this phenomenon in the texts here discussed. Two poems published under the name "GMP," both opaquely entitled "Lines," are presented with no subtitle or other indication of subject matter other than their epigraphs $(O O 7 \mathrm{Sept}, 5$ Oct 1828). Byron's familiar name becomes in this case the first signal to the reader of the theme and content of the poems. In a similar maneuver, an epigraph from Byron's Giaour strikes the keynote for a poem titled "Revenge: A Fragment" (Calcutta Magazine [1831] iii.123-33). In other cases, Byron is explicitly cited as the main inspiration for a derivative work, as in "Hours of Imitation, No 1 - Lord Byron - A Fragment" (Calcutta Literary Gazette ix. 238); or a paratextual addition to the text is used to signal the poet's knowledge of his work, such as that offered by the author of "Flowers," who footnotes his reference to a "mystic chain" with the relevant line from Childe Harold: "The electric chain wherewith we are darkly bound" (Bengal Annual [1831] 319-20). Like "Revenge" and "Hours of Imitation", "Flowers" might be considered a second-order meditation on Byronic themes, approaching its subject matter through the lens of its source texts.

This kind of citation is not simply a matter of appropriating Byron's name as cultural capital, however; further investigation of these cases suggests a more complex engagement by the poet with the source text. The two sets of "Lines" cited above provide an example, as both adopt differing approaches to their source material. In one case, the epigraph, from 
Byron's "Song of Saul before his Last Battle," sets the tone for the work as a whole, as the poet expands on Saul's martial fervor:

Lead us on, Almighty Victor!

Scatter every hostile band.

Be our guide, be our Protector,

Till on Canaan's shores we stand! (OO 5 Oct 1828)

In the other case, the poem is constructed in implicit opposition to its epigraph, from "On this Day I Complete my Thirty-Sixth Year." While the source text implies its speaker's withdrawal from the world - "I tread reviving passions down ... In different should the smile or frown of beauty be" - the intertext responds to the lines and to the Byronic anticipation of a "soldier's grave" with a reply which affirms hope rather than resignation. "Awake - why fear the darkest hour - " is the opening line, and the poem ends on a rhetorical declamation of faith in a saviour God.

Though 'gainst thee Earth and Hell combine

Still on thy side is Power divine;

The Lord is all, and he is thine,

And will be thine for ever." (OO 7 Sept 1828)

Texts such as these demonstrate the ability of the writers concerned to make strategic use of their Byronic models, engaging in creative dialogue with their source texts while also seeking to associate their work with the themes and images given poetic weight by Byron's fame. As these examples show, however, these appropriations of Byron are not obviously inflected or shaped by the specifically Indian experience of their writers. Further analysis of this body of texts focuses on responses to Byron that also constitute a response to some aspect of India in the British imagination.

\section{Byronic Satire}

Most of the adaptations of Byron discussed in this essay have not previously become the focus of scholarly investigation to any great extent, but both David Kopf and, following Kopf, Nigel Leask have offered accounts of one category of such works (Kopf 222-27; Leask "Anglo-Indian poetry" 52-85). This comprises the satires written on the model of Don Juan following the appearance of Cantos I and II in the Calcutta Journal in 1820. Many of these satires were printed in the Calcutta Journal in their turn; others appeared in other periodicals or as discrete publications. They include poems such as Ruin: A Familiar Tale of the East, "Rinaldo, or the Incipient Judge" (CJ 22 Jan, 1 Feb, 16 Feb 1822), and Tom Raw, the Griffin. 
The protagonist in each case is a disaffected employee of the East India Company, and the targets of satire include the Company's structures of law and government, the Orientalist emphasis on proficiency in the languages of India among its elite members, and both the British and the indigenous inhabitants of India encountered by the protagonist in the course of his hapless attempts to manage the demands of his employment and deal with debt, disease and the pitfalls of inter-racial sexual and social negotiations. These works imitate what Kopf describes as "Byron's literary style and predominant mood of melancholy", and they are characterised by their reliance on the episodic and picaresque plot of Don Juan as well as Byron's use of metre and narrative voice (222). This imitation is generally close enough to be unmistakable, whether openly acknowledged - as when the opening stanzas of Ruin, for instance, invoke Byron by name, with the narrator declaring that "I do copy him in style" (6) - or implicit, as in the use of ottava rima and a self-consciously Byronic narrator in "Rinaldo":

I have in Canto First distinctly said That So-and-so of Zillahs is the best;

And this assertion I am not afraid

Comparatively, fully to attest:

The picture which I have above display'd,

Undoubtedly disproves what I've express'd;

The lines in stanza next tho', will, I trust,

Convince you that the character is just. (CJ 1 Feb 1822)

In works like these, Byronic forms, voice, and plot-structure are clearly appropriated to serve the purpose of representing some of the concerns of the British community in India. Looking beyond those satires discussed by Kopf and Leask, however, reveals a wider and more diverse set of adaptations of Byron, not confined to the work of those who would simply reclothe Don Juan in the dress of a disaffected servant of the East India Company.

The main difference between the smaller set of Byronic satires and this wider category lies in the authors' readiness to experiment, as their work reveals a series of nuanced responses to the themes as well as the formats of Byron's oeuvre. Thomas D'Arcy Morris, a celebrated writer of satires and an officer in the Bombay army, constructs his own version of Don Juan as a review of a hypothetical poem, "The Griffin," the "maiden effort of an Indian Subaltern's Muse." This text, which exists only in the form of passages quoted within the review, describes itself as "written in burlesque imitation (if we may use such a phrase when the thing burlesqued is in itself a Burlesque) of Lord Byron's witty yet shamelessly indecent 
Don Juan; void of all its richest beauties and destitute also of its licentiousness and depravity" (Bombay Gazette 30 Aug 1820). Serialized in six parts over five months, the review / poem followed its protagonist's encounters with Bombay society, and embroiled its writer in a court case when the original of a dashing female character recognised herself and was recognised by her social circle. ${ }^{14}$

This turn of events notwithstanding, Morris's subject in this poem is not only the protagonist, and the Bombay society he encounters, but also the literary establishment of Britain, in the person of the supposed reviewer of his work. Untroubled by any knowledge of the jargon of British India, the reviewer is led by the title of "The Griffin" to expect a "tale of German Horrors, a tissue of deaths heads and blue lights" (Bombay Gazette 30 Aug 1820), rather than the account of a novice traveller to India; he further comments with distaste upon the "disgusting minuteness" (6 Sept 1820) with which the poem describes the inhabitants of the country. For Morris's Bombay audience, the metropolitan reviewer's ignorance of and distaste for India is the main target for satire.

While Morris's work thus plays with the review form, it also leaves intact the structure of the hypothetical poem within it, a shadow version of Don Juan. This basic structure reappears in another verse narrative of a young man's encounter with the world, "Azim: A Tale of Khorassan." The poem was serialized in the Meerut Universal Magazine in 1836, and a handwritten note in the British Library copy ascribes the poem to Henry Miers Elliot, one of the three editors of the paper. It takes its title and the name of its protagonist from "The Veiled Prophet of Khorassan," one of the embedded narratives of Moore's Lalla Rookh, but its metre and voice are derived from Byron, as the final stanza demonstrates:

Here I'll conclude, just where I ought, my tale,

It has one little merit, 'tis a new one;

And though the images are rather stale,

And though the metre is the same, Don Juan

Boasts of - I've stolen as little as a frail

Weak poetaster could (and I'm a true one.)

So if you should detect a verse or two,

Excuse it - and I'll do the same to you. (MUM 3 (1836) 293)

The narrative, set in the Persian province of Khorassan, follows the story of the protagonist Azim and his wife Zelima (or Selima as her name appears in the final canto). Although they make their way through a standard romance narrative (he buys her from a slave trader, albeit with her own money; he is attacked by robbers and left for dead), the plot is desultory at best, 
culminating in a contrived ending where the penniless couple, wandering through the countryside after their escape from the robbers, reach a "splendid city" whose ruler has just died. The inhabitants welcome them and proclaim them the new king and queen, in accordance with custom (MUM 3 [1836] 291-92). While the ostensible topic, then, is the Eastern romance, this plot is used mainly as a springboard for the narrator to comment on matters pertaining more closely to British society in India. Azim's bankruptcy, for instance, becomes the occasion for a parenthetical attack on the agency houses of Calcutta, where a banking crisis in the early 1830 s led to the failure of several establishments:

Look at those Agents in Calcutta now,

Who've sent all Indians but themselves to pot:

Fergusson, Alexander, Palmer - how

Can I name all? - Mackintosh, and a knot

Of others, but not one in Jail I trow -

Pray! what cared they for smashing - do they not

Pocket at their constituents expense - some

Thousand Rupees, or double that, per mensem? (MUM 1 (1835) 125)

Other incidents and themes of the story are also used by the narrator to reflect the concerns and pursuits of the British in India. The Fort William College education in Persian and indigenous languages (undergone by civil servants of the East India Company on their first arrival in India) underlies Zelima's search for appropriate subject matter for her embroidery. This task leads her to a meditation on the classic texts of the Persian canon, whereby her voice is elided with that of the narrator, as she recalls (among other texts):

... Ferdousi's Epic,

A poem most insufferably long,

And if you read it through 'twould make you sick,

Three times the length of Homer's glorious song

About the fall of Troy! but you can pick

Most splendid passages; and I am not wrong,

When, like Sir William Jones, to this I add

Equal to anything in the Iliad. (MUM 2 (1836) 42)

Elliot was one of those who studied in Fort William College and was awarded medals for his proficiency in Persian and Arabic (Wahi 65). Despite these achievements, and his invocation of William Jones, the most celebrated of Orientalist scholars, he shares with the writers of the Calcutta Journal discussed above a marked scepticism about the value of his education: 
Well, out of this same poem she decided

To choose the subject that she now required,

And actually read it through, as I did

When with a vain ambition I aspired

To be ambassador in Fars, and prided

Myself upon the Persian I'd acquired;

All this I thought of in Fort William College,

Where I gained many prizes, but no knowledge. (MUM 2 (1836) 43)

In thus bringing together an Eastern subject matter and a colonizing narrative voice, Elliot's poem might be classified as a hybrid literary form, translating Byron's model of Don Juan's naive engagement with the world to a colonial context where Eastern literary traditions and Orientalist knowledge both fall victim to the narrator's sophisticated disenchantment with India.

Other versions of Byron's work continue to be used as the basis for satire during this period. "Know ye the Land," identified by its epigraph with Byron's "Bride of Abydos," takes its meter and subject matter from the latter work while relocating it from the Turkish land of the "cypress and myrtle" to Ireland, land of the "turf and the whiskey," where the "Zephyr, oppressed with perfume" (Byron 209) becomes the "Potheen (best drink that is known)" (OO 24 Jul 1831). They often invoke Byron's best-known works, from the instantly recognizable anapaestic tetrameter of Byron's "Destruction of Sennacherib," which provides inspiration for a hunting song where the charging Assyrian of the original becomes a hunter of boar; to a comic version of "Ye Sadde Tale of Sir Childe Harry," whose protagonist avoids the excesses of his namesake by careful attention to his mother's advice. ${ }^{15}$ One of the consistent features of these texts is the fact that it is not the Byronic form per se which is parodied or satirized. Rather, the comic effect is achieved by a contrast between the register and subject matter of the source text - or "hypertext," in Genette's terminology (Palimpsests 5) - and the banal materiality of British India described in the hypotext. The opening of the fourth canto of Childe Harold's Pilgrimage, with its famous account of Venice as "a sea Cybele, fresh from ocean, / Rising with her tiara of proud towers" (Byron 512), finds a satiric echo in the first lines of the pseudonymous Cheshunt Owen's tragic-comic "Frederick and Flora: A Romance of Today," where the narrator invokes Calcutta as "City of mango-fish, and oily butter," before Byronically charging his "kind Muse" to "conduct thee with propriety," avoid "any long digression, / Resist the sentimental vein" and "stick to thy story" (Calcutta Magazine 1831 593-94). Another revision of "Bride of Abydos" produces a 
satirical "Bride of Calcutta," where the romantic cypress and myrtle are replaced by the "sewers and ditches" of the city (Bombay Courier 4 Dec 1846). In these and the other poems discussed in this section, Byron's verse forms and themes become the means by which the unequal colonial relationship between a dependent and disparaged India (or Ireland) and Britain is reiterated. At the same time, the poems' status as imitations and adaptations, second-order versions of Byron's works, underlines the relationship of literary dependence between the writers of British India and their metropolitan counterparts.

\section{Transformations of the Byronic Hero}

This relationship of dependence is evident again in texts from the third category of responses to Byron: poems where an Indian protagonist is represented using the model of the criminal or deviant hero. The figure generally termed the "Byronic hero" - a charismatic, self-willed, solitary individual, both attractive and dangerous - has antecedents preceding Byron himself, and also appears in varying forms in the work of many authors of the Romantic and Victorian periods and beyond (see McGann (19-35), Elfenbein, Stein). Peter Thorslev's foundational account has the Byronic hero representing "a rebellion which asserted the independence of the individual and the primacy of his values not only in the face of society, but even in the face of God" (172). Byron's own version of this figure often takes the form of the "noble outlaw" (in Thorslev's phrase), a man self-isolated from the wider society and living in defiance of its values, such as the protagonist of Childe Harold:

But soon he knew himself the most unfit

Of men to herd with Man; with whom he held

Little in common; untaught to submit

His thoughts to others, though his soul was quell'd

In youth by his own thoughts; still uncompell'd,

He would not yield dominion of his mind

To spirits against whom his own rebell'd;

Proud though in desolation; which could find

A life within itself, to breathe without mankind. (Byron 418)

Other such figures include the protagonists of "The Giaour," "The Corsair," "Lara" and "The Bride of Abydos." The bands of outlaws, rebels, or bandits who accompany some of these protagonists, such as Conrad's corsairs or the warlike Albanians encountered by Childe Harold, might also be considered to fall within this category, though they are given group 
identities rather than presented as fully-realized individuals. The followers of Byron within British India translated the noble outlaws of his work into India as dacoit or bandit leaders, many of whom derive most immediately from the characters of Conrad in "The Corsair" and the eponymous Giaour. ${ }^{16}$ The solipsistic, violent protagonists of poems such as "The Decoit" by Henry Barkley Henderson and "The Dacoit” by Samuel Sloper share recognizably Byronic characteristics. In many cases, the poems are written in a format avowedly or implicitly derived from Byronic models.

These British Indian versions of the Byronic "noble outlaw" are both like and unlike their originals for reasons mainly to do with the specific historical and political circumstances of the British experience of India. In the first thirty years of the nineteenth century, the status and legitimacy of the colonial state were still in question across a large part of the territory of British India. The final episode of the Maratha Wars (1817-18), beginning with operations against the Pindari marauders, ended with the British exercising direct or indirect control over most of north India. Among the consequences was a breakdown in the social and economic order across this landscape: indigenous ruling groups were dispersed, unemployed soldiers from the Company's armies joined increasing numbers of dispossessed or landless people who had no role in the new social organization, and they, along with surviving Pindaris, were rebranded as dacoits, thugs, or bandits. ${ }^{17}$ Those who had opposed this new order, for whatever reason, were now cast as criminals rather than rebels. Against the background of this history, it becomes apparent that there is no room in the literature of British India for the ambiguous dual figure of the criminal who is also a semi-legitimate rebel against an oppressive state authority, such as Conrad becomes in "The Corsair." This figure finds an echo in British India, but in a form that alienates him from the reader.

A comparison of "The Corsair" with a text by Thomas Medwin, one of the writers of British India whose work is strongly influenced by Byron, shows how this alienation is achieved. ${ }^{18}$ The opening lines of "The Corsair" introduce the pirates and their lifestyle in strikingly positive and attractive fashion:

O'er the glad waters of the dark blue sea,

Our thoughts as boundless, and our souls as free,

Far as the breeze can bear, the billows foam,

Survey our empire, and behold our home!

These are our realms, no limits to their sway -

Our flag the sceptre all who meet obey.

Ours the wild life in tumult still to range 
From toil to rest, and joy in every change.

Oh, who can tell, save he whose heart hath tried,

And danced in triumph o'er the waters wide,

The exulting sense - the pulse's maddening play,

That thrills the wanderer of that trackless way? (Byron 250-251)

The text invites the reader to identify in imagination with the pirates, sharing in the excitement and the freedom of their "wild life." Despite the fleeting reference to their "plunder'd wealth" (271), the pirates, and Conrad their leader, are firmly established as at least partially sympathetic figures before any attempt is made to represent their violent and predatory behavior. Even then, the account of "groaning victims and wild cries for life," with Conrad himself a "glutted tiger mangling in his lair!" (274), is set against their impulse to "spare the weaker prey" (275) and save the women from the flames.

In Medwin's “The Pindarees," by contrast, Byron's image of the tiger strikes the keynote of the account, unleavened by any show of chivalric or generous behavior on the part of the bandits. Rather, they are defined from the start through an emphasis on their selfcentered urge to consume and their inhumanity:

[They]...count their feats of outrage on the way,

Like tigers dreaming o'er their mangled prey;

These from their girdled waist drew forth a prize

Of lettered gold to feast their comrades' eyes;

Anklets, and armlets, those of women shewed;

And some of infants, not unstained with blood. (49)

The note to these lines adds the further detail that children's limbs were removed, the easier to take their jewelry (84). Rather than be inspired to join these bandits, the reader's natural response would be to hope for their defeat, which the text duly supplies: "Their forces routed and their leader slain" (78). The ambivalent, romanticized pirates of Byron's source text are reduced to one-dimensional abhorrent figures.

A similar effect is evident in other transformations of Byron's works, where the "antiimperialist views" (Oliver 135) expressed in poems such as Childe Harold's Pilgrimage are absent, or replaced by colonizing voices, in the poetry of British India. A case in point concerns Childe Harold's encounter with Albania in Canto II. Several critics have argued convincingly that Byron's account of this episode, based on his own travels in the country, demonstrates his willingness to represent the "fierce" and wrathful Albanians (Byron 115) as 
"upholders of individual freedom against the threat of Imperial domination," and the land itself as a location for resistance to "imperial or colonial" hegemony (Oliver 142-143). As Leask points out in "Byron and the Eastern Mediterranean," the embedded war-song of the Suliotes is particularly significant in this respect, as Byron chooses to avoid equating the Suliotes with criminals (as his traveling companion John Hobhouse did), but rather to focus on their military successes against opponents including French and Russian forces, in the "moment when Previsa fell" (Leask 119, Byron 118-119).

The sympathy towards resistance to imperial domination demonstrated by Byron in this instance is not shared by many among the British in India. It is particularly lacking in the anonymously published "Parody: On Childe Harold's Song of the Suliotes" (Oriental Sporting Magazine Nov 1831 238). In this version, Byron's warlike Albanians are replaced by followers of the sport of boar-hunting, a favorite pastime of British officers in India. The work is faithful to the meter and form of the original, as the following example demonstrates, but the attitude of the speaker is markedly different:

Shall the sons of Chimari, who never forgive $\mid$ Shall the sons of old England, thus exiled The fault of a friend, bid an enemy live? Let those guns so unerring such vengeance forego?

What mark is so fair as the breast of a foe? afar,

Not enjoy the best sport in the land where they are?

For your guns so unerring I care not a fig;

What mark is so fair as the rump of a pig?

(OSM 238)

In this text, the voices of those represented by Byron as figures of resistance to imperial oppression are no longer heard; instead, the hunting song is voiced by the "sons of old England," representatives of the British colonial power. The indigenous population of India the most obvious parallel for Byron's Suliotes - are not represented at all: the land appears to be empty apart from the pigs that become the object and reward of British colonial sport. In this parodic version of Byron's encounter with the Orient, the warlike qualities of the colonized are assimilated into the image of the British colonizing self.

Other texts adopt a variant strategy, imagining a colonized voice and presence, while simultaneously disempowering it. "The Decoit: A Fragment" is the product of another British army officer, Henry Barkley Henderson, a close and attentive reader of Byron. "The Decoit" is preceded by an announcement that it was written "almost immediately after perusing Lord Byron's Giaour," and an acknowledgement of the "faint and humble attempts, here made, to 
imitate [its] style" (80). The product of these efforts is a very close imitation of Byron's work, from the turbulent hero to the fragmented narrative and the plot turning on the killing of a woman. The tortured anti-hero of the Giaour is transferred to an Indian setting and given the name of Omeer, the eponymous "blood'stain'd, bold decoit" (82). Concealing the fact of his criminality, he lures his beloved Ahmeera from "country, friends and home, / With him in sin and love to roam" (87). This act proves his downfall: when Ahmeera decides he has been unfaithful to her, the "slighted maid" seeks out the "Sahib," or commander, ${ }^{19}$ of the armed forces, and gives away the secret of his location (92-93). Omeer is defeated in battle and compelled to take "shameful flight" (96). He then kills Ahmeera in revenge and surrenders to the Sahib as a prelude to suicide by poison: "Fearless, unforc'd, myself have come / To ask for death - and meet my doom!" (100). The remainder of the poem reprises the Giaour's final confession to his Abbot (Byron 207-208): the bandit explains himself to a silent British listener, and boasts of his power and pride. He finally commits suicide by drinking poison, in a very Byronic conclusion of power and impotence and damnation combined:

"I told the Sahib, his threats were vain,

E'en now the poison fires my brain;

I drank as from a madding bowl,

And ah! it parches up my soul:

Tott'ring I stand o'er Hell's wide brink,

No hand to save - I plunge! - I sink! -

Hold, Hold!" - The murd'rer spake not more -

He paus'd: for now the drug's fell pow'r,

In fierce convulsions tore his frame,

Till death in guilty horror came. (108-9)

Several aspects of "The Decoit" are characteristic of this group of texts more generally. First, the structure of the work emphasizes the power of the bandit, but also emphasizes how that power is contained. He speaks at some length, his voice the only one so directly heard in the latter part of the text, and this verbal command of the scene contrasts with the passivity of the voiceless British commander. At the same time, however, the speaker is contained within a frame narrative; this distances him from the reader, and the narrative voice both places and defines him in the last lines, naming him a murderer and insisting on his guilt. At other times in the poem the reader is similarly discouraged from empathizing too closely with Omeer, who is described as a fratricide and a killer of his friend (86-87). Despite his absence from the dialogue of the scene, the British sahib is in some ways 
a more powerful figure than Byron's Abbot: he acts as Omeer's “confessor," listening to his story, but he wields temporal as well as spiritual authority; he stands as the representative of the political and legal order of the British state in India that is stronger for Omeer's downfall. The overall effect is to represent the bandit as a dramatic, psychologically compelling figure, in many ways an intriguing protagonist, but one always contained by the authority of the colonial state. $^{20}$

Similar characteristics are visible in Samuel Sloper's narrative poem "The Dacoit," which opens on a bandit's wife pining for her absent husband and goes on to describe his criminal life, his eventual defeat and death at the hands of British forces, and her consequent suicide. While the poem celebrates its bandit protagonist's courage and generosity, it falls short of representing him as a heroic or exemplary individual. The framing of the narrative, starting and finishing as it does on the account of the bandit's wife expressing her anguish at his absence and loss, focuses the reader's attention on the human and emotional cost of the bandit's self-centered actions. True heroism in the story is reserved for those who oppose him, the disciplined and gallant British officers and Indian troops who are together referred to as the "soldiers bearing England's name" (Sloper 12).

Other such poems acknowledge the charismatic energy of the bandit figures and the freedom of their lives, but they also focus, like Medwin's work discussed above, on the impact of the bandits on their victims. James Hutchinson's "The Pindarree" adopts as its model Byron's "The Destruction of Sennacherib" and echoes its original in content as well as in form: the movement from the vigor of the opening lines to a final image of desolation is apparent in both works. In Hutchinson's poem, the agents of destruction are again Pindaris or raiders. The protagonist's dashing, picturesque strength is emphasized, as is the access to power represented by his "long spear," and his prancing charger. Their freedom is apparent in the details of their clothing - "Loose streams to the wind his white-flowing garb" - and their way of life, again reminiscent of Byron's corsairs: "Their beds are the ground, and their curtains the sky." By the end, however, the tone has changed, as the poem closes on the image of the ruined village they leave behind, its inhabitants gone:

All roofless and black is their desolate home

And their daughters dishonor'd are weeping in vain,

Nor will glory in youth or in beauty again. (Bengal Annual [1834] 198-199) For exile readers, that image of the "desolate home," "roofless and black," might be especially potent, making it unlikely that the poem could be read against the grain as a celebration of banditry without a determined and rather perverse effort. 
The notable feature, then, of this set of textual transformations of the Byronic hero appears to be the absence of any Byronic sympathy or identification with colonized figures any trace of what Murray Pittock calls "fratriotism," or "the adoption of colonized nations and cultures as a means of expressing reservations concerning the nature and development of empire, of seeing oneself in the other" (29). Rather, these colonial incarnations of the Byronic hero tend to re-inscribe the boundaries between the colonizing self and the colonial other, closing off avenues of identification between reader and colonial subject and resolving the ambiguous criminal / hero of Byron's works to become the criminal object of justice. Although this is by far the most prevalent aspect of this body of work, it is not exclusively present. In a few cases, the "noble outlaw" of Byron's work appears in something like its original form, and in each case, the context for this seems to be a writer who does not fully identify with the colonial project of the British state in India. This essay concludes with an examination of two such writers: Mary Jourdan and W. F. Thompson.

\section{Anti-colonial Nationalism and the Byronic Hero}

Mary Jourdan, who published her first poems under the name "Mrs Major Jourdan," was affiliated with the British army in India through her father, an army officer, as well as through her marriage; but she is also clearly less directly connected with the machinery of administration than Henderson, Sloper or Hutchinson, all military or civil employees of the East India Company. As Mary Procida argues, British women in India occupy an ambivalent relationship to the colonial state, sustaining it and dependent upon it through their connections of marriage or kinship with its employees, but also alienated from it by their gender. ${ }^{21}$ It is this ambivalence which underlies Jourdan's poetry. A reader of Byron, who used a quotation from Childe Harold's Pilgrimage as epigraph to her long poem "The Ocean's Own" (Althorp Picture Gallery 79-121), she also appropriated his metrical forms and a version of the Byronic hero for "The Pindarry to his Steed."

The model for this poem is Byron's "Mazeppa" (1819), ${ }^{22}$ specifically the protagonist's embedded narrative of his wild ride on horseback across the countryside. Mazeppa is, in fact, a helpless prisoner during his journey, having been stripped naked and bound to his horse as punishment for the illicit relationship he has entered into. By the second stanza of the ride, however, the account carries a paradoxical emphasis on freedom:

Away, away, my steed and I,

Upon the pinions of the wind,

All human dwellings left behind; 
We sped like meteors through the sky,

When with its crackling sound the night

Is chequer'd with the northern light. (Byron 614)

Jourdan's poem closely echoes the original, and in particular the repeated refrain of "Away, away," transforming Mazeppa's narrative of freedom within bonds into a celebration of the unity between the rider, his horse and their surroundings:

Hurrah! Hurrah! we scud away,

Beneath the full hot eye of day;

Buoyant, and poised on fresh'ning air,

The monarch bird is hov'ring there;

He gains, - battling the blast's fierce sea, -

With one fell swoop, his lone eyrie;

An emblem, as he onward flew,

My noble steed, of me and you. (Bengal Annual [1830] 347)

These lines evidence the same action and energy that characterizes the bandit portrait in the other poems, but here action is represented for its own sake, an exuberant performance of the bandit's control over his surroundings. "The Pindarry to his Steed" eroticizes, and inhabits, a specifically masculine body: the emphasis is from the start on the physical and sensual - the sun is the "full hot eye of day" - and the actions of horse and rider are described in terms verging on the orgasmic, with explosive action followed by calm:

Hurrah! Hurrah! He paws the wave,

As proud the opposing stream to brave.

Hurrah! Hurrah! - one struggling strain, -

'Tis done! - the rising bank we gain;

Oh! linger not: - like raging wind

The crowding foe comes fast behind;

One gasp, - one shake, - fling off the spray, -

One long-drawn breath, - away! away!

Hurrah! Hurrah! the hills are won,

Well hast thou sped, - thy task is done;

White foam rests on thy heaving side,

Still reeking from the oozy tide;

Restlessly fierce thy bright black eye, - 
Thy labouring breath comes pantingly; -

But stay thee now without a fear,

And calmly sleep thy master near! (Bengal Annual [1830] 348)

The poem describes a solipsistic, desiring performance of masculinity and power that is not directed against any other person. There are no pathetic victims in the margins, and the nearest thing to any kind of impact the bandit has on the world is when the wild animals of the forest are frightened and move out of his path. So although the title names him a "Pindarry" - a clear signal to the contemporary reader that this is an outlaw - there is no formal or thematic barrier to the reader's identification with the bandit figure. The protagonist is represented as in harmony with "Nature's wild elements," his analogue is the "monarch bird," "poised on fresh'ning air"; he exists as a figure of power and desire wholly outside of the colonial context - and is therefore entirely a figure of wish-fulfillment. ${ }^{23}$

In the main body of this poetry, the psychodrama of the bandit's life ends with the protagonist being displaced as well as defeated: while at the beginning he is often an attractive or charismatic figure, in death or imprisonment he is re-contextualized as a criminal threat to the state, whose dis-arming is a possibly regrettable but necessary part of the colonial process and the march of history. In Jourdan's poem, the bandit figure is removed from the contemporary social or political context: in the absence of any clash with an oppositional state power, the bandit figure is left in possession of his surroundings, king in his own imagined realm. Jourdan's deployment of this figure might be considered a form of gender and cultural cross-dressing - a theme common in the literature of orientalism, but more often associated with men adopting Eastern dress, such as the explorer Richard Burton or Rudyard Kipling's fictional character Strickland the policeman. The bandit "costume" becomes a masculine disguise within which the female writer can imaginatively inhabit a freedom not generally open to her. The writing of British women frequently presents India as a threatening land - a place of heat, disease, early death, dust and scorpions (Suleri 75-110) but through the eyes of Jourdan's bandit it becomes a location of conquest and of mastery. Andrew Elfenbein argues that many British women writers of this period used the Byronic hero in their work, "not merely as an object of desire but as a figure for themselves as authors," suggesting that "the figure was available not solely for desire and admiration, but also for imitation and identification" (65). Following this line of argument, it might be suggested that Mazeppa, who narrates his story in the first person, becomes a model of autonomy and agency, ${ }^{24}$ unavailable to the woman writer of British India in her own person, but appropriated by her in order to recuperate another figure excluded from the colonial 
order, the bandit.

This imaginative identification with the outlaw / bandit figure is taken a step further by W. F. Thompson, whose poetry demonstrates an unusual readiness to explore the state of mind of such individuals. Thompson's career took him along a conventional path from Haileybury College to the civil service of the East India Company and a series of administrative posts in Bengal. He was widely read in contemporary and classical literature and history and had an abiding interest in British linguistic and cultural encounters with the Islamic tradition, evident in his production of several works of commentary and translation. ${ }^{25}$ His disaffection with the approach and goals of the British administration is particularly visible in the anonymously published poem India, which describes the British as a "blight" on India, oppressing and victimising its people (79). Another poem, "The City of the East," is apocalyptically negative about the plight of the employees of the East India Company, who arrive in India expecting to occupy positions of power and authority, but find themselves corrupted by the servility of those they govern while their youth and physical strength give way to decadence and decay, leaving them "deject and impotent" (19). Within Thompson's nihilistic vision of India, there are few positive or empathetic depictions of anyone, British or Indian. The exception is the kind of rebel or bandit figure other writers demonized. The "Hindoo Bandit," for example, is depicted in lines such as these:

On! on! thro' the forest - away! away!

We'll ride with the mid-night blast;

And the smoke of the village, the shrieks of the prey

Shall tell where our footsteps past! (Bengal Annual [1836] 196)

The debt to Byron's "Mazeppa" is evident despite the change in meter, and the twin attributes of freedom and a predatory indifference to society recall both the pirates of "The Corsair" and the inhumane bandits of Medwin's “The Pindarees." Unlike Medwin's and the other bandit figures discussed above, Thompson's bandits do not act with unjustified malice, but are given a rationale for their behavior: "They drove us from lands and they drove us from homes, / Let them look, let them look to their own" (196). "They" in this poem are not further identified; but in Thompson's other works, there are persistent signs that such oppressors are British. India, for example, concludes in anticipation of an Indian rebellion against British rule to mirror contemporary nationalist insurgence against some of the oppressive regimes of Europe (85-87); and "The Jogi's Address to the Ganges" refers with contempt to the reign of "Mlechhas" (foreigners, non-Hindus) in India and further characterizes these as "pale-faced" (Bengal Annual [1834] 233). ${ }^{26}$ 
In another poem, “The Rajpoot's Lament" (1835), Thompson takes this identification with the colonized a step further, assuming the voice of an Indian from the Rajput states, a location associated by the British with martial and chivalric people. ${ }^{27}$ The Rajput speaker laments the oppression of his land and people by invaders:

The Cheytrie's pride, the Brahmun's god,

Shall both be trampled and o'erthrown,

And the pure land, your footsteps trod,

Debased by lords to you unknown. (Bengal Annual [1835] 382)

As with the "Hindoo Bandit," the identity of these oppressors is not specified in so many words (the British, but also the Mughal invaders before them, might be described in this way). However, the reference to them as "slaves of slaves, whose god is gold" (382) suggests the intended target might be the East India Company, which started its existence as a commercial trading company and had by the 1830 s only just made the transition into a de facto institution of the British government. Regardless of this identification, the important point is the characterization of the speaker, who is taken out of the criminal context of the bandit poems and endowed with a selfless dedication to individual and national liberty:

'Tis vain, the task is not for me -

Fly, baseless hope and shadowy throne -

My country's soul I cannot free,

I will be master of my own:

Enough for me if freedom's eye

Shall mark my ashes as they lie,

And freedom's tardy hand confer

A wreath on him who died for her. (384)

Thompson's sympathy for those who would seek self-determination and freedom from imperial aggression is not commonly to be found among the British in India. Although little is known of his life beyond the bare details of his career, the manner of his death - suicide following a period of 'aberration of mind' (Asiatic Journal Feb 1843 149) - suggests that he was troubled by personal as well as political issues. His work, like that of Jourdan, nonetheless indicates that those working in the shadow of the East India Company could, and occasionally did, engage with subjects and forms of writing radically at odds with those produced under the normal circumstances of colonial life.

The tradition of Anglo-Indian poetry from which these works are drawn has only in 
recent years become the object of literary scholarship, as part of a larger movement towards retrieval and re-examination of texts and authors previously considered marginal to a nineteenth-century canon. Despite occasional instances of literary creativity and craftsmanship, the amateur and derivative nature of this body of work is not in question: in most cases, the tropes and meters popularized by Byron are adopted wholesale and without nuance. The intersection of these Byronic elements with the specific cultural and political contexts of the British community in India, however, produced a body of poetry capable of giving a distinctive thematic and formal expression to the concerns of its writers. The main concern in the texts discussed here is the British encounter with India and with the Indian colonized "other"; the social order and legitimate authority sought by the British state are constituted against the Byronic figure of the solipsistic criminal bandit. The literature of British India calls into being this "other" figure in opposition to the colonial order, but in doing so also exposes the permeable nature of the boundary between colonizer and colonized. This permeability is particularly evident in the work of Jourdan and Thompson, where the bandit figure becomes identified with an impulse to personal or national freedom in an imaginative incorporation of the colonial "other" within a fantasized version of the colonizing self.

University of Nottingham

\section{NOTES}

1. See Gibson (72-73, 160-65), and Chaudhuri (Gentlemen Poets). The influence of Byron's work on poets and playwrights writing in Bengali and Hindi remains a topic largely unexplored, but a valuable essay by Poddar goes some way towards indicating the scope and range of these writers' uses of Byronic models; see also Trivedi (100-02).

2. See St Clair (227). C.R. Johnson notes the tendency for Byron to become "a subject for many authors" as well as influencing their work (preface, n.pag.). Samuel Chew describes some contemporary literary responses to Don Juan (27-43); see also Andrew Elfenbein's account of the "creation of Byronism" (47-89).

3. See Gibson (108-16). H.H. Spry, a writer of prose rather than poetry, but otherwise representative of the military and civilian professional classes who produced most of the works discussed in this essay, writes in 1833 of having "a decent supply of books of my own" and also had access through the Book Club in Saugor, where he was stationed, to "all the periodical publications of the day as well as all the new works as they are published" (SpryLeverton 338). 
4. Buckingham and the Indian liberal reformer Rammohan Roy were co-proprietors of the Calcutta Journal. Buckingham's editorial policies brought the paper into conflict with the East India Company administration, and he was eventually deported, leading to its closure in 1823. See Bayly.

5. The Oriental Observer sometimes carried the alternative title the Oriental Literary Observer, and in the latter years was also known as the Oriental Observer and Literary Chronicle; these variations are disregarded in this essay, and items from the paper are referenced with the abbreviation $O O$.

6. See, for instance, "Lord Byron's Mazeppa” (CJ 25 November 1819), which appears preceded by an account of the "difficulties of procuring the New and Popular Publications of Europe" (CJ 25 November 1819); see also the review of Childe Harold's Pilgrimage Canto IV (CJ 31 January 1819), reprinted from the Edinburgh Review.

7. See, for instance, extracts from Don Juan (CJ 17 Jan 1822); an engraved portrait of the poet (CJ 1 Aug 1820); a Byron article in a series of "Sketches of the Living Poets" (CJ 22 Jan 1822); and an article on Byron copied from the Times of 27 Dec 1821 (CJ 27 May 1822). 8. See the "Son of the Morning" correspondence (CJ 4 Jul, 13 Jul, 1 Aug, 4 Aug, 19 Aug, 26 Sept 1819); Philo-Yacoob, “Lord Byron’s Don Juan” (CJ 2 Jan 1821); A.B., “Lord Byron’s Werner" (CJ 29 Apr 1823).

9. See also Rob Roy, “To Lord Byron on reading his Don Juan” (CJ 3 Jan 1821).

10. See, for instance, reviews of Moore's Life of Byron (Calcutta Magazine [1830] 422-26); and Galt, Life of Lord Byron (Calcutta Magazine [1831] 155-71). The editor of the Calcutta Literary Gazette (1826-35), David Lester Richardson, frequently reprinted Byron's work and discussed his poetry and his life; see, for example, the pieces collected in Literary Chit-Chat. 11. These works, with the possible exception of the last, are reprints from imported publications.

12. Delta, "Fragments," part 3, Madras Literary Gazette (1834) 455; the full text is serialized over several issues $(322-3 ; 338-9 ; 347-8 ; 455-6)$.

13. I have not sought in this essay to classify or nuance further the uses made of Byron's work by those who read and responded to him. Julie Sanders suggests a distinction between adaptation, which "signals a relationship with an informing sourcetext or original," and appropriation, which "frequently affects a more decisive journey away from the informing source into a wholly new cultural product and domain" (26). As further discussion will show, I would contend that the difference or distance apparent between a text and its successor in 
this particular context is more to do with the political and cultural circumstances of the transaction than the result of a deliberate decision on the part of the writer.

14. "From the ***** Review, Published at London by Richard Paterson, \& Co., 25 Long Lane, Third Edition - with Plates," Bombay Gazette 30 Aug 1820; further installments appeared on 6 Sept, 20 Sept, 25 Oct, 6 Dec and 27 Dec. See the contemporary obituary of Morris included as a note to "The Bheels," Asiatic Journal (Nov 1835) 165.

15. "For the O.S.M." (Oriental Sporting Magazine 2 [Nov 1831] 235); see also C.J. Muller, "Babylon" (Orient Pearl [1835] 216-20); "Ye Sadde Tale of Sir Childe Harry (Mofussilite 5 Nov 1847).

16. Other contemporary models also influenced the representation of the bandit figure in this tradition, most notably the outlaw-rebels of Walter Scott, such as Rob Roy MacGregor; a full discussion is beyond the scope of this essay.

17. Recent scholarship has focused on this process as a precursor to the East India Company's preoccupation with thugs and other criminal communities in the first half of the nineteenth century. See Singha (168-228).

18. Leask suggests that Medwin's Indian poems might be considered "mere pastiche versions of Byron's Eastern Tales, appropriating Byron's verse couplets as well as elements of character and narrative" (“Anglo-Indian Poetry" 66).

19. The term "sahib" by the nineteenth century had come to indicate a British person in a position of authority; the poem describes this figure alternatively as the "Captain" commanding the troops who are themselves Indian "seapoys," or soldiers (Henderson 100).

20. Although this paper focuses on poetry, it should be noted that Taylor's widely-read Confessions of a Thug also uses this technique to render an Indian protagonist subordinate to a British "sahib" confessor.

21. Procida's analysis relates to a period later than that covered by this essay, but the gender dynamics of the British state and society in India remained largely unchanged from the 1830s onwards.

22. An early version of this paper was delivered at the BARS conference in Glasgow (2011); I am indebted to the participants who commented on my work, and in particular to Nigel Leask, who recognized Jourdan's use of "Mazeppa."

23. In a later edition of her work, Jourdan adds a footnote which supplements the poem with an account of the Pindaris as "fiery and lawless spirits," and includes both a reference to the "helpless ryots, or cultivators of the soil" who were their victims, and the achievement of the 
British government in India which "extirpated these migratory robbers" (Mind's Mirror 19596). The poem itself, however, is otherwise substantially unchanged.

24. Mazeppa's function as an "empowering figure" is discussed in another context by McLean (111).

25. The range of Thompson's interests is apparent in the inventory of his possessions compiled after his death: a list of books in English and Persian runs to several pages and includes works of fiction, poetry (including 4 volumes of Byron) and history (Inventories and Accounts IOR L/AG/34/27/127, ff. 16-31). See also ní Fhlathúin 2.1-15.

26. "The Jogi's Address to the Ganges" is also notable in that it owes its theme and some of its imagery to Byron's work: see “On Jordan’s Banks” (1815).

27. This image was developed and publicized by James Tod, whose Annals and Antiquities of Rajast'han was widely read at this period.

\section{Works Cited}

\section{Periodicals}

Asiatic Journal

Bengal Annual

Bombay Courier

Bombay Gazette

Calcutta Journal

Calcutta Literary Gazette

Calcutta Magazine

Madras Literary Gazette

Meerut Universal Magazine

Mofussilite

Orient Pearl

Oriental Observer

Oriental Sporting Magazine

\section{Other sources}

Adams, Matthew. "Furnishing the Colonial Mind: Book Ownership in British India, 17801850.” Economic History Society. 2006. Web. 14 Oct 2012.

Bayly, C.A. "Rammohan Roy and the advent of constitutional liberalism in India, 18001830." Modern Intellectual History 4.1 (2007): 25-41. 
Byron. Lord Byron: Selected Poems. Eds. Susan Wolfson and Peter J. Manning. London: Penguin, 2005. Print.

Chaudhuri, Rosinka. Gentlemen Poets in Colonial Bengal: Emergent Nationalism and the Orientalist Project. Calcutta: Seagull, 2002. Print.

Cheem, Aliph. Lays of Ind, $2^{\text {nd }}$ series. Bombay: Times of India office, 1873. Print.

Chew, Samuel. Byron in England: His Fame and After-Fame. London: John Murray, 1924. Print.

Derozio, H.L.V. Derozio: Poet of India. Ed. Rosinka Chaudhuri. Delhi: Oxford UP, 2008. Print.

Elfenbein, Andrew. Byron and the Victorians. Cambridge: Cambridge UP, 1995. Print.

Genette, Gérard. Palimpsests: Literature in the Second Degree. Trans. Channa Newman and Claude Doubinsky. Lincoln: U Nebraska P, 1997. Print.

---. Paratexts: Thresholds of Interpretation. Trans. Jane E. Lewin. Cambridge: Cambridge UP, 1997. Print.

Gibson, Mary Ellis. Indian Angles: English Verse in Colonial India from Jones to Tagore. Athens, OH: Ohio UP, 2011. Print.

[Henderson, Henry Barkley.] The Goorkha and Other Poems. Calcutta, 1817. Print. Hutchinson, James. The Pilgrim of India: An Eastern Tale, and Other Poems. London: Pickering, 1847. Print.

---. The Sunyassee, an Eastern Tale: and Other Poems. Calcutta: Thacker; London: W.H. Allen, 1828. Print.

Inventories and Accounts of Deceased Estates - Bengal, Madras and Bombay 1843, part 2. IOR L/AG/34/27/127. British Library.

[Jourdan, Mary Johnson]. Mind's Mirror: Poetical Sketches. Edinburgh: James Hogg; London: Groombridge, 1856. Print.

[---]. The Althorp Picture Gallery and Other Poetical Sketches. Edinburgh: Blackwood, 1836. Print.

Kipling, Rudyard. "Miss Youghal's Sais.” Plain Tales from the Hills. Calcutta: Thacker, Spink, 1888. Print.

Kopf, David. British Orientalism and the Bengal Renaissance. Berkeley and Los Angeles: U California P, 1969. Print.

Leask, Nigel. "Byron and the Eastern Mediterranean." The Cambridge Companion to Byron. Ed. Drummond Bone. Cambridge: Cambridge University Press, 2004. Cambridge Collections Online. Web.12 September 2012. 
---. "Towards an Anglo-Indian Poetry? The Colonial Muse in the Writings of John Leyden, Thomas Medwin and Charles D’Oyly.” Writing India, 1757-1990. Ed. Bart MooreGilbert. Manchester: Manchester UP, 1996. 52-85. Print.

McGann, Jerome. Byron and Romanticism. Ed. James Soderholm. Cambridge: Cambridge UP, 2002. Print.

McLean, Thomas. The Other East and Nineteenth-Century British Literature: Imagining Poland and the Russian Empire. Basingstoke: Palgrave, 2012. Print.

Medwin, Thomas. Sketches in Hindoostan, with Other Poems. London: Ollier / Simpkin and Marshall, 1821. Print.

Moore, Thomas. Lalla Rookh: An Oriental Romance. London: Longman, 1817. Print.

ní Fhlathúin, Máire. The Poetry of British India. 2 vols. London: Pickering \& Chatto, 2011. Print.

Oliver, Susan. Scott, Byron and the Poetics of Cultural Encounter. Basingstoke: Palgrave, 2005. Print.

Pittock, Murray. Scottish and Irish Romanticism. Oxford, Oxford UP, 2008. Print.

Poddar, Arabinda. "Lord Byron and the Literary Renaissance in Bengal." Indian Literature: Proceedings of a Seminar. Ed. Arabinda Poddar. Simla: Indian Institute of Advanced Study, 1972. 116-24. Print.

Procida, Mary. Married to the Empire: Gender, Politics and Imperialism in India, 1883-

1947. Manchester: Manchester UP, 2002. Print.

Richardson, David Lester. Literary Chit-Chat. London: James Madden, 1848. Print.

Ruin: A Familiar Tale of the East. Calcutta: Scott, 1820. Print.

Saglia, Diego. “Orientalism.” A Companion to European Romanticism. Ed. Michael Ferber. Oxford: Blackwell, 2005. 471-72. Print.

Sanders, Julie. Adaptation and Appropriation. Oxford: Routledge, 2006. Print.

Scott, Walter. Rob Roy. Edinburgh, 1818. Print.

Singha, Radhika. A Despotism of Law: Crime and Justice in Early Colonial India. Delhi: Oxford UP, 2000. Print.

Sloper, Samuel. The Dacoit and other Poems. London: Simpkin, Marshall, 1840. Print.

Spry-Leverton, Jeffery, ed. The Spry Letters. 1985. BL Photo Eur308. British Library.

St Clair, William. The Reading Nation in the Romantic Period. Cambridge: Cambridge UP, 2004. Print.

Stein, Atara. The Byronic Hero in Film, Fiction and Television. Carbondale, IL: Southern Illinois UP, 2004. Print. 
Suleri, Sara. The Rhetoric of English India. Chicago: U Chicago P, 1992. Print.

Tambe, Shrikant R. English Muse on Indian Soil. Bangalore: Ultra, 1999. Print.

Taylor, Philip Meadows. Confessions of a Thug. London: Bentley, 1839. Print.

[Thompson.W. F.] India: A Poem. London: Priestley, 1834. Print.

[---.] The City of the East, and other poems. London: Priestley, 1837. Print.

Thorslev, Peter. The Byronic Hero: Types and Prototypes. Minneapolis: U Minnesota P, 1962. Print.

Tod, James. Annals and Antiquities of Rajast'han, or the Central and Western Rajpoot States of India. London: Smith Elder, 1829-32. Print.

Tom Raw, the Griffin. London: Ackermann, 1828. Print.

Trivedi, Harish. Colonial Transactions: English Literature and India. Manchester:

Manchester UP, 1995. Print.

Wahi, Tripta. "Henry Miers Elliot: A Reappraisal." Journal of the Royal Asiatic Society NS 1 (1990): 64-90. 